\title{
WAGE DETERMINATION WITH SPECIAL REFERENCE TO ROLE IN A FAMILY
}

\section{Lenka Filipová, Zuzana Machová}

VŠB - Technical University of Ostrava, Faculty of Economics, Sokolská třída 33, 701 21 Ostrava 1, lenka.filipova@vsb.cz, zuzana.machova@vsb.cz

\begin{abstract}
The paper has arisen as a part of the project dealing with the questions of measuring of wage determinants and wage discrimination on the basis of different subjective requirements of women and men on their wages. Using the ordered-response model (Ordered Probit), it analysed wage determination on the basis of Mincer's Wage Regression including dummies for role in a family. The analysis was carried out with the total sample of respondents and subsequently separately for men and women. The data were gained from a questionnaire survey carried out in Ostrava city, Czech Republic. In general, the analysis did not prove previous conclusions of theories or empirical studies about prevailing influence of family characteristics on the wage rate. Nevertheless, it proved statistically significant differences in the wage determination between men and women, and showed that in the case of men, some family characteristics may have been important for determining the wages.
\end{abstract}

Key words: Human Capital, Role in a Family, Wage Determinants, Wage Discrimination.

JEL Classification: J24, J31, J71

DOI: $10.2478 / \mathrm{v} 10135-011-0006-\mathrm{y}$ 


\title{
WAGE DETERMINATION WITH SPECIAL REFERENCE TO ROLE IN A FAMILY ${ }^{1}$
}

\author{
Lenka Filipová, Zuzana Machováa
}

\begin{abstract}
Introduction
Wages are an important indicator in expressing human capital value. The standard Neoclassical theory of the labour market states that wages (the marginal costs of labour) should correspond with income from the marginal product of labour under the conditions of ideal competition. This principle is the basis for standard human capital theory which assumes that the amount of wages is influenced by the personality characteristics affecting labour productivity. Mincer (1974) expressed the relation of human capital to the amount of wages through a wage equation which has become the methodology basis for simulating wage determinants up to the present.
\end{abstract}

More sophisticated theories have been developed (such as those by Dickens and Katz (1987) or Krueger and Summers (1988), see further), modifying Mincer's wage regression by adding a labour status description (the position in one's employment, working hours, type of employment contract, and qualification requirements), corporate factors (how large a company is, commercial and non-commercial sectors, and industries), institutional factors (legislation protection of employment and the minimum wage) and regional factors, which are now collectively referred to as wage determinants; any differences in wages are due to these determinants.

If the wage differentiation is not explained by objective wage determinant characteristics, it is referred to as wage discrimination. ${ }^{3}$ Nevertheless, no economic studies have worked with the sociological aspect of different requirements of men and women for the wage rate. According to sociological studies (Dudová, 2007; Hašková, 2003; Křížková, 2006; Moe, 2003 etc.), the unexplained differences in wages do not have to be caused by discrimination but different preferences of men and women, namely in relation to family existence. 'General' (gender) stereotype places an emphasis on the 'caring person type' and the 'family breadwinner type', with these types prevailingly matching the 'simple' division by gender. A shift in this perception is seen in single-parent families. Men tend to put an emphasis on the caring type (part-time jobs and lower wages) while women on the income for the family (full-time jobs and higher wages). Where there are no children, the differences become blurred. The role of an individual in the family can then be seen as one of the wage determinants. This can be set in the preference theory which, as a part of the neoclassical economy, presents

\footnotetext{
${ }^{1}$ The paper is supported by the SGS research project SP/201016 „Measuring Wage Determinants and Wage Discrimination", which is aimed at the analysis of wage determinants and discrimination according to gender on the basis of different subjective requirements of women and men on their wages.

${ }^{2}$ VŠB - Technical University of Ostrava, Faculty of Economics, Sokolská tř́́da 33, 70121 Ostrava. Email: lenka.filipova@vsb.cz, zuzana.machova@vsb.cz.

${ }^{3}$ Measuring the extent of wage discrimination on the basis of Oaxaca-Blinder decomposition of wage differences is the objective of authors' further research.
} 
standard economic explanation of the decision-making process of individuals. Since Gary Becker (Theory of preferences, 1997) this theory has gained its relevance for all aspects of life decisions.

The aim of this paper is to analyze the influence of the family characteristics on the wage determination of men and women.

For our purpose, it is necessary to connect a contemporary economic quantitative research of wage determinants with a sociological qualitative research of the impact of family roles and preferences on wage. The analysis is methodologically based on the modified Mincer wage regression, where the vector of explanatory variables includes three types of factors: personal, firm and family characteristics.

The first part of the article includes the summary of present knowledge of the issue in question on both theoretical and empirical level. The second part focuses on the description of data acquired by questionnaire survey carried out in the territory of Ostrava city and methods of their processing. The third part includes the results of the econometric analysis.

\section{Theoretical and empirical background}

The approach usually used for wage determinants measuring is Mincer's approach based on the theory of human capital which reflects personal characteristics of individuals. According to this theory, an employee's wage is determined by the quality given by education, general working experience, specific working experience acquired in the company and other qualities independent of education and experience. Empiric literature ${ }^{1}$ proved Mincer's wage function to be valid in basic and modified forms and also in countries with different institutional structures. However, the proportion of education and experience to explain differences in wages between employees varies by country and it ranges approximately from $30 \%$ to $50 \%$.

There are many studies using Mincer's wage regression for wage differences determination in the Czech and Slovak labour market. The detailed analysis was carried out by, among others, Filer, Jurajda and Plánovský (1999). The rate of investment return indicator into education in 1997 ranged from $6.5 \%$ to $9.0 \%$ per year and reached much higher values than stated by Flanagan (1995) for 1991 and by Chase (1998) for 1993, which means an increasing significance of education in the labour market. Later era (around 2002) was elaborated in the study of Gottvald et al. (2002).

Other theories of wage determinants emphasize differences in occupation characteristics, for instance the theory of job competition. The connection of the theory of human capital and the theory of job competition is carried out by allocation theory which shows that people are characterized by skills, and that job vacancies are characterized by complexity. There can be comparative advantages when employing particular individuals in particular jobs which are used when there is an effective labour market.

\footnotetext{
${ }^{1}$ A very good overview of this literature can be found in the Handbook of Labor Economics, North-Holland Publishing Company, 1999. Basic references include Gery S. Becker and B. R. Chiswick, "Education and the Distribution of Earnings", American Economic Review 56, 1966, pp 358 - 369 and Jacob Mincer, "Schooling, Experience and Earnings", New York: Columbia University, 1974.
} 
The hypothesis of effective wages (Dickens and Katz, 1987; Davis and Haltiwanger, 1996) justifies the inclusion of indicators such as the branch of industry, how large a company is and for how long it has existed. Active trade unions (Freeman and Medoff, 1986; Pencavel, 1991) justify the inclusion of the types of collective bargaining. Internal wage structures (Krueger, 1993; Lazear, 1998) justify the inclusion of tenure. Thus, wages are determined by personal characteristics, job vacancy characteristics and institutional and market characteristics.

Much more present foreign research in the field of explanation of wage differences between men and women uses not only economic approaches but also approaches from other socioscientific disciplines, e.g. psychology or sociology. Their results show different behaviour of men and women in relation to their employability in the labour market (Jacobsen, 2007). In this context other factors influencing this behaviour are studied as well, e.g. influence of the government and its institutions, existence of the family and position of both genders in it (Boje, 2001; Moe, 2003). Length of maternity leave is one of the factors of differences in wages. Although this subject is very important from a political as well as an academic point of view, currently, there are only a few studies that deal with this subject and analyze the impact of the length of maternity leave on wages and employment of mothers and their results are not conclusive, see Ejnaes and Kunze (2004), Schoenberg and Ludsteck (2007), Würtz (2007) or Dustmann and Schoenberg (2008). The results of similar studies show different levels of preferences of men and women in relation to the employment, for instance different requirements for the length of employment but also in the negotiations about wage rate. The theory of preferences then explains a search for optimum combination of work and other activities in life that brings a person the highest satisfaction possible. The position of each person on the labour market, as well as their rate of participation in the other activities, is a result of their individual free choice realized in certain social conditions.

So far, studies referring to the Czech Republic and other transitive economies have focused especially on changes in the labour market during the transformation period and their influence on wage differences between men and women. Jurajda (2001 and 2003) says that women's hourly wages are up to $30 \%$ lower than men's hourly wages in the Czech Republic, whereas in the Slovak Republic, the wage difference is lower, especially in the public sector. In the private sector, approximately two thirds of wage differences are explained by discrimination factors in both republics. Jurajda (2005) says that despite antidiscrimination policies have been introduced in the $\mathrm{CZ}$, segregation of women into low-wage jobs is the significant source of wage differences between men and women.

Academic studies focusing on blending and harmonizing professional and family life carried out in the Czech Republic and Slovakia point to the fact that organization of careers and professional lives in couples still usually disadvantages professional life of women to men's career. Gender scheme or regulation is applied with respect to the types of a 'caring person type' and the 'family breadwinner type,' which in absolute majority correspond to the gender-based division. The studies also represent notions about care distribution and paid work in the partners' life. These notions are compared to care actually taken and work assignment (Hašková et al., 2003; Křŕžková et al., 2006.). 


\section{Ordered probit model of wage determinants: data, methodology and variables}

In the project called Measuring Wage Determinants and Wage Discrimination a questionnaire survey was carried out, the aim of which was to acquire data relating to wage determinants of individual respondents according to Mincer's theory, their subjective requirements for wage rate and status in the family. The basic set researched was the 'prime-age' working population of the city of Ostrava. As the features of the basic set are known from Population and Housing Census carried out in $2001,{ }^{1}$ the method chosen was quota selection which ensures consistent structure of the basic and the selective set. Quotas ${ }^{2}$ were provided for sex, age and field ${ }^{3}$ which individual respondents work in.

The survey was carried out in the city of Ostrava from May 26, 2010 to July 1, 2010. 399 questionnaires were distributed in total, out of which 391 were completed properly. Subsequently, the selection of 300 questionnaires was made in order to meet the established quotas. For further validation of consistency between the basic and selective set structures with respect to defined quotas, a hypothesis of relative frequencies equality was tested for each quota. Results of statistic tests confirmed relative frequencies equality on the significant level of $5 \%$ and the selection can therefore be considered as representative.

The wage determinant analysis is based on a standard model stemming from Mincer's wage regression which is besides personal characteristics extended by traditional institutional and corporate characteristics. However, the aim of the research is following particularly other influences on the wage rate which are based on sociological studies emphasising the influence of roles in the family on the wage rates. If the analysis confirms the influence of family status and roles in the family on the wage rates, it will change the view of gender-based discrimination. Part of the questionnaire would be also questions related to the care of children and household.

Therefore, the distribution of selection set frequencies is shown in the following two charts with respect to the care of children and household (hereinafter "care") according to the sex, education and wage rate before the econometric analysis. The question about prevailing care offered respondents three types of responses: I take care mostly; my partner takes care mostly, and we both take care equally. Only respondents having children and with the marital status married or single living in common household were included in the charts.

The first chart shows that responses of common care prevail for both sexes and education, the second position is prevailing care of the particular respondent and least respondents granted prevailing care to the partner. The responses of university educated men are interesting, they grant prevailing care for themselves in $29 \%$, only $7 \%$ of them responded the partner and the rest, i.e. $64 \%$ responded equal care. Whereas in the case

${ }^{1}$ ČSÚ, 2005.

${ }^{2}$ With respect to the fact that survey respondents were only working people, it was not possible to set quotas for education as ČSÚ provides only Population and Housing Census results for the whole population and it can be assumed that the educational structure does not correspond with the educational structure of working population, in other words there are more people with low education among unemployed people.

${ }^{3}$ See Population and Housing Census 2001. 
of university educated women, $12 \%$ of respondents stated the partner as the prevailing caretaker, $24 \%$ granted the care for themselves and $65 \%$ stated equal care with the partner. The distribution of responses of skilled men is interesting as well, $22 \%$ of them granted the prevailing care to their partners, $19 \%$ to themselves and $59 \%$ equal care.

From this data distribution it is obvious that in case of subjective characteristics of role perception in the household it would be proper to specify and choose questions more precisely, so as not to be psychologically marked. Besides the question about the care of children, there could have been written the question about the risk losing the employment in the questionnaire. Here, an individual prefers job security with usually lower wage or prefers the employment with the higher prestige and higher wage but with a larger degree of responsibility and competition in the field or profession and thus a higher risk. The question about the care of children and household could have been specified to average number of hours spent with children daily, not the vague formulated question about prevailing care. Moreover, there might have been written so called check questions which could have helped to eliminate too subjective views of the question. For instance the question about the number of hours spent with children could be supported by the question about the average working hours a day, etc. This should be taken into consideration for the future research.

Table 1: Children care according to sex and education

\begin{tabular}{|c|c|c|c|c|c|c|c|c|}
\hline & \multicolumn{7}{|c|}{ Children care } \\
\hline Sex & Education & $\mathrm{Me}$ & $\%$ of total & Partner & $\%$ of total & Equally & $\%$ of total & Total \\
\hline \multirow[t]{4}{*}{ Male } & Primary & 2 & 33 & & & 4 & 67 & 6 \\
\hline & Training & 5 & 19 & 6 & 22 & 16 & 59 & 27 \\
\hline & High & 1 & 7 & 1 & 7 & 12 & 86 & 14 \\
\hline & University & 4 & 29 & 1 & 7 & 9 & 64 & 14 \\
\hline \multicolumn{2}{|c|}{ Total of Male } & 12 & 20 & 8 & 13 & 41 & 67 & 61 \\
\hline \multirow[t]{5}{*}{ Female } & Primary & & 0 & 2 & 100 & & 0 & 2 \\
\hline & Training & 6 & 25 & & 0 & 18 & 75 & 24 \\
\hline & High & 12 & 30 & 2 & 5 & 26 & 65 & 40 \\
\hline & Clollege & & 0 & & 0 & 2 & 100 & 2 \\
\hline & University & 4 & 24 & 2 & 12 & 11 & 65 & 17 \\
\hline \multicolumn{2}{|c|}{ Total of Female } & 22 & 26 & 6 & 7 & 57 & 67 & 85 \\
\hline \multicolumn{2}{|l|}{ Total } & 34 & 23 & 14 & 10 & 98 & 67 & 146 \\
\hline
\end{tabular}

Note: figures in the table state absolute numbers of respondents. Only the \% of total columns represents the percentage of a particular category to the total number of respondents in the particular row.

The distribution of responses to the question about the care of children and household shows slightly rising proportion of responses granting prevailing care to the partner with the wage rise. Though, it is not possible to assume any more significant ties between wage and care of children and household from such data distribution. 
Table 2 Children care according to net wage ${ }^{1}$

\begin{tabular}{|l|c|c|c|c|c|c|c|}
\hline & \multicolumn{7}{|c|}{ Children care } \\
\hline Net wage & Me & \% of total & Partner & \% of total & Equally & $\%$ of total & Total \\
\hline to $10000 \mathrm{CZK}$ & 4 & 27 & 2 & 13 & 9 & 60 & 15 \\
\hline $10001-16000 \mathrm{CZK}$ & 11 & 20 & 5 & 9 & 38 & 70 & 54 \\
\hline $16001-22000 \mathrm{CZK}$ & 9 & 20 & 2 & 4 & 34 & 76 & 45 \\
\hline $22001-28000 \mathrm{CZK}$ & 6 & 30 & 3 & 15 & 11 & 55 & 20 \\
\hline $28001-34000 \mathrm{CZK}$ & 1 & 17 & 2 & 33 & 3 & 50 & 6 \\
\hline $34001-40000 \mathrm{CZK}$ & 1 & 33 & & 0 & 2 & 67 & 3 \\
\hline $40001-46000 \mathrm{CZK}$ & 1 & 100 & & 0 & & 0 & 1 \\
\hline $52001 \mathrm{CZK}$ and more & 1 & 50 & & 0 & 1 & 50 & 2 \\
\hline Total & 34 & 23 & 14 & 10 & 98 & 67 & 146 \\
\hline
\end{tabular}

Note: figures in the table state absolute numbers of respondents. Only the \% of total columns represents the percentage of a particular category to the total number of respondents in the particular row.

Traditional model of wage determinants is simply expressed by the following equation:

$\ln W_{i t}=X_{i t} \beta+\varepsilon_{i t}$,

where $i$ represents an individual and $t$ time period. Dependent variable (wage) is expressed in a logarithmic form and $\mathrm{X}$ represents independent variables vector, in this case wage determinants. Theory of human capital is the theoretical foundation of this specification and coefficients are interpreted as earnings from investments into the human capital. $\varepsilon$ represents an error term.

In this analysis, however, it is not possible to express wage in the logarithmic form and to use the method of least squares as the wage is created in categories. Ordinal logit or probit models are usually used for categorically explained variables. Eviews Software uses the ordered-response model (Ordered Probit) with analytic second derivative methods to obtain parameter and variance matrix of the estimated coefficient estimates (Quadratic hill climbing) for the partivular variable type.

Hence, the model has the following form:

$W_{i}=X_{i} \beta+\varepsilon_{i}$,

where $t$ index is missing as data only for one observation period are used. Explanatory variables have the character of dummy variables. In total, 10 variables are used for wage determinant definition, out of which 3 represent personal characteristics stemming out of Mincer's wage regression (sex, age, education), 4 characterize institutional and corporate factors (ISCO ${ }^{2}, \mathrm{NACE}^{3}$, ownership, company size). For our purposes of observation of the influence of family status on wage rate, there are 3 other variables

\footnotetext{
${ }^{1}$ Net wage means disposable for respondents.

${ }^{2}$ International Standard Classification of Occupations.

${ }^{3}$ Nomenclature générale des Activités économiques dans les Communautés Européennes (classification of economic studies).
} 
used in the analysis, 2 of which are objective (number of children, marital status) and one variable represents subjective view of the role in the family in the question who is involved more in care-taking of children and household.

Vector $\mathrm{X}$ involves the following variables.

A: personal characteristics stemming from Mincer's wage equation:

- dummies for gender,

- 4 dummies for age (in categories),

- 5 dummies for education.

B: institutional and corporate factors:

- dummy variables for 10 ISCO categories,

- dummy variables for 21 NACE categories, 1

- dummy variables for 2 types of ownership,

- dummy variables for 6 company size categories.

C: characteristics of family status and roles in the household:

- number of children as dummies for 6 categories,

- family status - single or married/partnership,

- care of children - dummies for 3 categories: me prevailing, partner prevailing, both equally.

As mentioned above, the data sample includes 300 individuals: 146 men and 154 women. First, the analysis was carried out with the total sample of respondents, subsequently separately for men and women. First, all the variables mentioned above are included, then the separately personal characteristics, institutional and corporate characteristics and family characteristics to verify economic significance including variables into the analysis.

Results of the total respondent sample (see Table 3 in the Appendix) show that the model is statistically significant as a whole, as LR statistics came out statistically significant. There had to be made slight adjustments in explanatory variables as for the integration of some categories which were marked for great variability in observation and the software could not process calculation of coefficients with such unbalanced data. This category adjustment was used for all following analysis. Category integration was made in the following cases:

- education (1 primary + 2 vocational education; 3 secondary with "maturita" exam +4 college),

- $\quad$ ISCO (ISCO $1+2$; ISCO $6+7$; ISCO $8+9$ ),

- number of children (category $4+5+6$, which equals 3 and more children).

The variable explained is marked for great variability of the number of observations as the following figure shows. Hence, categories were integrated here too, namely $5-9$, and analysis was carried out for original and new categories separately. The results did

\footnotetext{
${ }^{1}$ NACE had to be excluded from the analysis. Ordered probit model did not allow to include this variable into the calculation, as some categories include only very little observation sample and category integration would not bring any economic significance in case of the field.
} 
not differentiate much, which is the reason why the original wage categorization is stated below and used for the result interpretation.

\section{Figure 1: Frequency of net wage}

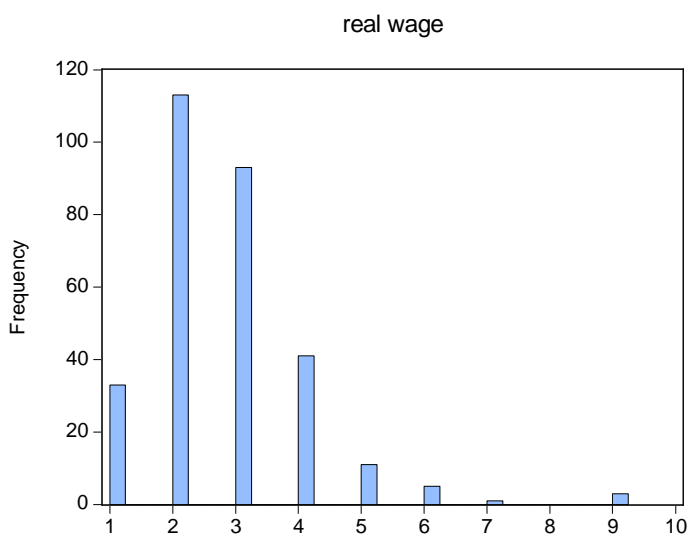

Note: real wage description equals net wage in our sense. Real wage was used in the questionnaire for comprehensibility for respondents as the description of real wage on their accounts.

\section{Analysis and results}

Mincerian presumptions about wage determinants were confirmed from the point of view of variables, i.e. the influence of personal characteristics. Sex and age variables are statistically significant. From corporate statistics only company size variable proved to be slightly statistically significant, namely with categories 4 and 5 (250 to 5000 employees). From family statistics only the number of children variable is slightly statistically significant, namely in the category 3 and more children only.

However, coefficient interpretation is more complex in cases of models with qualitatively (categorically) explained variable given than in the case of the OLS method. Here coefficient shows the probability to change the category of the explained variable with the change of particular explanatory variable (result is calculated for extreme, or end categories), whereas it is not possible to determine which category of explained variable is referred to. The result only shows whether the category is going to increase in case of coefficient plus sign (in our case it will be higher wage), or in case of coefficient minus sign to decrease, i.e. the explained variable drops to lower wage. In our case it is essential to take into account the fact that other (explanatory) variables are expressed in the categories as dummy variables as well, i.e. in order to be clear, the result needs to be interpreted in comparison to reference category which represents first dummy variable (category). Thus, for instance the variable coefficient SEX_2 (women) shows that women have higher probability that their wage will be in the low-wage category than men; or for instance the variable coefficient EDU_5 (university education) says that university educated people have higher probability that their wage is in the high-wage category in comparison to people with primary education and vocational education. This analysis does not include variables related to the subjective 
view of the care of children as it would mean to exclude childless households from the analysis, thus the loss of the particular sample of individuals.

Furthermore, only analysis (see Table 4 in the Appendix) of personal characteristics on the basis of Mincerian wage equation was carried out. Here the statistical significance and the value of coefficients with particular variables do not differ from the previous equation which points to the fact that personal characteristics play a significant role for wage rate determination, as the theory of human capital suggests. The only exception in comparison to the previous equation is an explicit, albeit very weak statistical significance of age, namely with the category AGE_2 (30 - 39 years). The coefficient shows that people in this age category have higher probability that their wage will range within the higher categories than in case of the reference age category, which is $20-29$ years.

When following institutional and corporate characteristics, all categories except for ISCO_3 - Technicians and associate professionals proved (see Table 5 in the Appendix) to be statistically significant. According to the presumptions, there is a coefficient minus sign with all followed ISCO categories pointing at the probability of lower wage in comparison to the reference category, which is ISCO 1 and 2 (Managers and Professionals). The property variable is also statistically significant when employees in the private sector have greater probability of higher wages compared to the public sector. The company size indicator does not influence wages significantly, only categories 4 and 5 (250 - 4999 employees) marked weak statistical significance with plus coefficient values which represent the probability of higher wage in comparison to reference category (up to 10 employees).

If we include only subjective and family characteristics into the equation, the model as a whole is statistically insignificant (see Table 6 in the Appendix), for the reason that except for family status, no category out of those statistically significant variables has a significant impact on wage category. STATUS_2 category coefficient shows that married couples or people living in partnership have higher probability that their wage is in higher categories.

\section{Analysis for men and women separately}

The analysis carried out separately for men and women showed differences in statistical significance for wage determinants. When including all variables, the model came out statistically relevant for both men (see Table 7 in the Appendix) and women (see Table 8 in the Appendix). With men, statistical relevance appeared in case of personal characteristics with the age category 4 (40 - 49 years), with minus, then with both educational categories with the presumed plus coefficient sign.

Furthermore, it was necessary to aggregate ISCO categories into larger units (ISCO $1,2,3$; ISCO 4,5,6; ISCO 7,8,9) for the calculation than in the case of analysis of the total sample. This aggregation is used for the rest of the component analysis. From corporate characteristics, category ISCO 4,5,6 with plus sign is slightly statistically significant; company ownership (employments in private sector have higher probability of higher wage category than employments in public sector); company size categories 4 and 5 again with plus sign. From family characteristics the number of children variable 
proved to be statistically significant, namely in categories 3 and more children, they have also 1.5 times higher probability of higher wage category.

With women the situation is different. Only the age variable in the category $30-39$ years with coefficient plus sign proved to be statistically significant from personal characteristics. The education variable did not prove to be statistically significant with women. Moreover, the university education category had to be excluded due to little number of observations. Corporate characteristics play a more significant role with women for wage rate determination. Basically, all observed variables and their categories were marked for statistic significance. The most impact proved to be in ISCO variable and in two other company size categories (4 and 5). Family characteristics do not play a significant role with women for wage rate determination; none of the variables is statistically significant.

When including personal characteristics stemming from Mincer's equation, the model with men came out statistically significant but only the education variable was statistically significant, namely in the university education category with the suggested plus sign showing the probability of higher wage categories. With women, the model with personal characteristics came out only slightly statistically significant, whereas the age category $30-39$ years with plus sign was slightly statistically significant only (ask authors for full results).

When analysing institutional and corporate characteristics separately (ask authors for full results), the model did not come out statistically significant for men as category ISCO 7, 8, 9 with the suggested minus sign was the only statistically significant variable from the observed characteristics. The other variables and their categories did not play any significant role with men for wage rate determination. With women the situation is opposite. When analysing corporate characteristics, the model came out statistically significant as all observed variables in all their categories are statistically significant. High statistic relevance is present especially in variable ISCO with coefficient minus sign, as if the ISCO variable compensated the importance of education. Company ownership and company size variables except for categories 3 and 6 are also significant. Nevertheless, the significance in other categories proves that categories according to company size are relevant for wage rate determination.

The analysis of family characteristics did not prove statistical significance with both men or women (ask authors for full results). With women none of the observed variable proved to be statistically significant, with men the family status variable and number of children variable in the category 3 and more children are slightly significant. Plus sign in the category STATUS_2 says that married men or men living in partnership have higher probability for higher wage category than single living men.

\section{Conclusion}

The aim of this paper was to carry out the analysis of wage determinants extended by family status and family roles characteristics. The research itself stemmed out of the hypothesis that the role in a family could have been the significant wage rate indicator. According to sociological studies, individuals can be divided into those who take care of children and household more, and those who work more and financially provide for the family. On the basis of the role in a family, it is possible to expect 
different requirements for the wage rate when persons taking care more will prefer greater job security usually connected with lower wage and vice versa persons working more will prefer more prestigious jobs with promotion possibilities and with the demand for a higher wage. This hypothesis corresponds to the theory of preferences which as a part of the neoclassical economy presents standard economic explanation of the decision-making process of individuals.

The analysis of wage determinants was based on the standard model stemming from Mincer's wage regression which was besides personal characteristics extended by traditional institutional and corporate characteristics. The model was lately complemented by other variables following the influence of family status and family roles on wage rate. If the analysis confirmed their influence on wage height, it would have also changed the view of gender-based discrimination which will be the subject of the authors' following research.

The results of the total respondent sample analysis showed that the model was statistically significant as a whole. From the variables point of view, Mincerian presumptions about wage determinants in particular proved to be right, i.e. the influence of personal characteristics. When analysing personal, corporate and family statistics separately, the models were statistically significant with statistically significant variables in case of personal and corporate characteristics. The model for family characteristics was not significant as the only statistically significant variable was the family status in this case. The other two family characteristics did not prove their significance.

The analysis carried out for men and women separately showed differences in statistical significance of wage determinants. When including all variables, the model came out statistically significant for both men and women. With men, personal characteristics such as education and age played an important role. When the analysis was carried out separately for personal, corporate and family characteristics, family status and the number of children, namely in the category 3 and more children, variables came out slightly statistically significant with men.

Statistical significance of education was not proven with women. Generally, the model with personal characteristics came out slightly statistically significant. On the contrary, corporate characteristics played an important role with women for wage rate determination, especially in ISCO variable (job classification). The model for family characteristics did not prove statistical significance; none of the variables was statistically significant.

The separate analysis for men and women proved that the family status and number of children could play a significant role in wage determination of men, i.e. men, unlike women, had higher probability of having higher wage in case they were married and had 3 and more children. If we consider men being the 'family breadwinner type' in most, the findings can indicate that a part of the difference in wages of men and women can be explained by the role in a family which reduces the extent of potential wage discrimination according gender.

Nevertheless, the above mentioned seems to be very week in the context of the whole analysis that in general did not prove previous conclusions of theories or empirical 
studies about prevailing influence of personal characteristics on the wage rate. The influence of family characteristics, especially family roles on the wage rate, failed to be proved. On the other hand, the problem can be seen especially in asking questions about the delicate topic of family roles which can bring rather psychologically marked and little objective responses. It should be advisable to take into account this aspect in future research. Furthermore, check questions which could help eliminate too subjective viewpoints of the question. For instance, the question about number of hours spent with children could be supported by the question about the average working hours a day, etc.

\section{References}

BOJE, T. P. (2001). Gender, Welfare State and the Market: Towards a New Division of Labour (Routledge Research in Gender and Society, 4). Routledge, London. ISBN: 0203-99228-8.

ČSÚ. (2005). SLDB 2001. Retrieved from http://www.czso.cz/sldb/sldb2001.nsf/index.

DAVIS, S. J.; HALTIWANGER, J. (1996). Employre Size and the Wage Structure in the United States. Annale d'Economie et de Statistique 41/42, 323-368.

DICKENS, W., KATZ, L. (1987). Inter-industry Wage Differences and Industry Characteristics. In: LANG, K., et al. Unemployment and the Structure of Labor Market. Basil-Blackwell, Oxford.

DUDOVÁ, R. et al. (2007). Development of Labour Market and Private, Family and Partner Life. Sociological Studies 07(3). Sociological Institute AV ČR, Prague. 165 s.

DUSTMANN, CH.; SCHOENBERG, U. (2008). The Effect of Expansions in Maternity Leave. Coverage on Children's Long-Term Outcomes. IZA Discussion Papers 3605. Institute for the Study of Labor (IZA).

EJRNAES, M.; KUNZE, A. (2004). Wage Dips and Drops Around First Birth. IZA Discussion Papers 1011. Institute for the Study of Labor (IZA).

FILER, R. K., JURAJDA, Š., PLÁNOVSKÝ, J. (1999). Returns to the Market: Valuing Human Capital in the Post-Transition Czech and Slovak Republic. CERGE-EI, Prague.

FLANAGAN, R. J. (1995). Wage Structures in the Transition of the Czech Republic. International Monetary Fund, IMF Staff Papers (4), 836-854.

FREEMAN, R. B.; MEDOFF, J. L. (1986). The Two Faces of Unionism. In: REYNOLDS, L. G.; MASTERS, S. H.; MOSER, C. H. Reading in Labor Economics and Labour Relations. Englewood Cliffs, Prentice Hall, N. J.

GOTTVALD, J. et al. (2002). Determinants of Individual Pay and Firms Pay Structures in the Czech and Slovak Republic. Technical University of Ostrava, Ostrava. ISBN 80248-0150-7.

HAŠKOVÁ, H. et al. (2003). Equal Possibilities of Men and Women When Harmonizing Work and Family?. Sociological Institute AV ČR, Prague. ISBN 80-7330048-6. 
CHASE, R. S. (1998). Markets for Communist Human Capital: Returns from Education and Experience in the Czech Republic and Slovakia. Industrial and Labor Relation Review 3, 401-423. Cornell University.

JACOBSEN, J. (2007). The Economics of Gender. Blackwell publishing. ISBN: 978-14051-6182-4.

JURAJDA, Š. (2001). Gender Wage Gap and Segregation in Late Transition. Working Paper 182, CERGE-EI, Prague.

JURAJDA, Š. (2003). Gender Wage Gap and Segregation in Enterprises and the Public Sector in Late Transition Countries. Journal of Comparative Economics 31(2), 199-222. Elsevier.

JURAJDA, Š., (2005). Gender Segregation and Wage Gap: An East-West Comparison. Journal of the European Economic Association 3(2-3), 598-607. MIT Press.

KRUEGER, A. B. (1993). How Computers Have Changed the Wage Structure: Evidence from Microdata, 1984-1989. Quarterly Journal of Economics 108 (1), 33-60.

KRUEGER, A. B., SUMMERS, L. H. (1988). Efficiency wages and the inter-industry wage structure. Econometrica 56, pp. 259-293.

KŘÍŽKOVÁ, A. et al. (2006). Pracovní a rodinné role a jejich kombinace v životě českých rodičů: plány versus realita. Sociologické studie/Sociological studies 06(14). Sociologický ústav AV ČR, Praha.

LAZEAR, E. P. (1998). Personnel Economics for Managers. John Wiley and Sons, New York.

MINCER, J. (1974). Schooling, Experience and Earnings. Columbia University, New York.

MOE, K. (2003). Women, Family, and Work: Writings on the Economics of Gender. Blackwell Publishing. ISBN: 0-631-22576-5.

PENCAVEL, J. (1991). Higher Education, Productivity and Earnings: A Review. Journal of Economic Education 22 (4), 331-359.

SCHOENBERG, U.; LUDSTECK, J. (2007). Maternity Leave Legislation, Female Labor Supply and the Family Wage Gap. IZA Discussion Papers 2699. Institute for the Study of Labor (IZA).

WÜRTZ, A. (2007). The Long-Term Effecton Children of Increasing the Length of Parents Birth-Related Leave. Department of Economics Working Paper 07-11. Aarhus School of Business. 


\section{Appendix}

\section{Table 3}

Sample: 1300

Included observations: 300

Number of ordered indicator values: 8

Convergence achieved after 5 iterations

\begin{tabular}{|c|c|c|c|c|}
\hline & Coefficient & Std. Error & z-Statistic & Prob. \\
\hline SEX_2 & -0.848307 & 0.162519 & -5.219733 & 0.0000 \\
\hline AGE_2 & 0.187437 & 0.205926 & 0.910219 & 0.3627 \\
\hline AGE_3 & -0.071725 & 0.234277 & -0.306156 & 0.7595 \\
\hline AGE_4 & -0.244319 & 0.240104 & -1.017555 & 0.3089 \\
\hline EDU_3_4 & 0.746601 & 0.181814 & 4.106390 & 0.0000 \\
\hline EDU_5 & 1.490093 & 0.252873 & 5.892652 & 0.0000 \\
\hline STATUS_2 & 0.018132 & 0.151529 & 0.119662 & 0.9048 \\
\hline ISCO_3 & -0.156457 & 0.236169 & -0.662478 & 0.5077 \\
\hline ISCO_4 & -0.276071 & 0.259500 & -1.063858 & 0.2874 \\
\hline ISCO_5 & -0.192397 & 0.298913 & -0.643655 & 0.5198 \\
\hline ISCO_6_7 & -0.254058 & 0.286624 & -0.886380 & 0.3754 \\
\hline ISCO_8_9 & -0.398214 & 0.286991 & -1.387549 & 0.1653 \\
\hline OWNER_2 & 0.275483 & 0.160247 & 1.719112 & 0.0856 \\
\hline FIRM_SIZE_2 & 0.200496 & 0.237612 & 0.843797 & 0.3988 \\
\hline FIRM_SIZE_3 & 0.097574 & 0.222725 & 0.438091 & 0.6613 \\
\hline FIRM_SIZE_4 & 0.690253 & 0.244900 & 2.818511 & 0.0048 \\
\hline FIRM_SIZE_5 & 0.668688 & 0.260625 & 2.565705 & 0.0103 \\
\hline FIRM_SIZE_6 & 0.392722 & 0.260997 & 1.504699 & 0.1324 \\
\hline CHILDREN_2 & 0.100712 & 0.220422 & 0.456904 & 0.6477 \\
\hline CHILDREN_3 & 0.237133 & 0.218062 & 1.087458 & 0.2768 \\
\hline CHILDREN_4_5_6 & 0.741318 & 0.292991 & 2.530179 & 0.0114 \\
\hline \multicolumn{5}{|c|}{ Limit Points } \\
\hline LIMIT_2:C(22) & -0.931091 & 0.396977 & -2.345453 & 0.0190 \\
\hline LIMIT_3:C(23) & 0.588157 & 0.396409 & 1.483713 & 0.1379 \\
\hline LIMIT_4:C(24) & 1.716988 & 0.403456 & 4.255699 & 0.0000 \\
\hline LIMIT_5:C(25) & 2.581186 & 0.415752 & 6.208467 & 0.0000 \\
\hline LIMIT_6:C(26) & 3.083134 & 0.432680 & 7.125671 & 0.0000 \\
\hline LIMIT_7:C(27) & 3.524463 & 0.464297 & 7.590967 & 0.0000 \\
\hline LIMIT_9:C(28) & 3.658612 & 0.478055 & 7.653120 & 0.0000 \\
\hline
\end{tabular}


Pseudo R-squared

Schwarz criterion

Hannan-Quinn criter.

LR statistic

Prob (LR statistic)
0.150241 Akaike info criterion

2.736209

3.081895

Log likelihood

$-382.4313$

2.874553 Restr. log likelihood

$-450.0471$

135.2315 Avg. log likelihood

0.000000

\section{Table 4}

Sample: 1300

Included observations: 300

Number of ordered indicator values: 8

Convergence achieved after 4 iterations

\begin{tabular}{|c|c|c|c|c|}
\hline & Coefficient & Std. Error & z-Statistic & Prob. \\
\hline SEX_2 & -0.925409 & 0.138460 & -6.683601 & 0.0000 \\
\hline AGE_2 & 0.401255 & 0.173230 & 2.316323 & 0.0205 \\
\hline AGE_3 & 0.242185 & 0.180751 & 1.339876 & 0.1803 \\
\hline AGE_4 & 0.131601 & 0.181200 & 0.726276 & 0.4677 \\
\hline EDU_3_4 & 0.726254 & 0.148295 & 4.897353 & 0.0000 \\
\hline EDU_5 & 1.504578 & 0.176837 & 8.508264 & 0.0000 \\
\hline \multicolumn{5}{|c|}{ Limit Points } \\
\hline LIMIT_2:C(7) & -1.186187 & 0.169214 & -7.009968 & 0.0000 \\
\hline LIMIT_3:C(8) & 0.280483 & 0.154185 & 1.819125 & 0.0689 \\
\hline LIMIT_4:C(9) & 1.356898 & 0.166480 & 8.150536 & 0.0000 \\
\hline LIMIT_5:C(10) & 2.181798 & 0.195026 & 11.18720 & 0.0000 \\
\hline LIMIT_6:C(11) & 2.657638 & 0.228974 & 11.60675 & 0.0000 \\
\hline LIMIT_7:C(12) & 3.066424 & 0.276517 & 11.08947 & 0.0000 \\
\hline LIMIT_9:C(13) & 3.187081 & 0.294803 & 10.81089 & 0.0000 \\
\hline Pseudo R-squared & 0.125076 & Akaike info criterion & & 2.711714 \\
\hline Schwarz criterion & 2.872212 & Log likelihood & & -393.7572 \\
\hline Hannan-Quinn criter. & 2.775946 & Restr. log likelihood & & -450.0471 \\
\hline LR statistic & 112.5798 & Avg. log likelihood & & -1.312524 \\
\hline Prob (LR statistic) & 0.000000 & & & \\
\hline
\end{tabular}




\section{Table 5}

Sample: 1300

Included observations: 300

Number of ordered indicator values: 8

Convergence achieved after 4 iterations

\begin{tabular}{|c|c|c|c|c|}
\hline & Coefficient & Std. Error & z-Statistic & Prob. \\
\hline ISCO_3 & -0.155146 & 0.226620 & -0.684611 & 0.4936 \\
\hline ISCO_4 & -0.808845 & 0.238228 & -3.395251 & 0.0007 \\
\hline ISCO_5 & -1.078983 & 0.258581 & -4.172714 & 0.0000 \\
\hline ISCO_6_7 & -0.746683 & 0.234634 & -3.182328 & 0.0015 \\
\hline ISCO_8_9 & -1.132370 & 0.232137 & -4.878025 & 0.0000 \\
\hline OWNER_2 & 0.404857 & 0.149855 & 2.701660 & 0.0069 \\
\hline FIRM_SIZE_2 & 0.101602 & 0.230116 & 0.441527 & 0.6588 \\
\hline FIRM_SIZE_3 & 0.029972 & 0.215751 & 0.138918 & 0.8895 \\
\hline FIRM_SIZE_4 & 0.466645 & 0.233534 & 1.998190 & 0.0457 \\
\hline FIRM_SIZE_5 & 0.485584 & 0.247600 & 1.961167 & 0.0499 \\
\hline FIRM_SIZE_6 & 0.251072 & 0.248718 & 1.009463 & 0.3128 \\
\hline \multicolumn{5}{|c|}{ Limit Points } \\
\hline LIMIT_2:C(12) & -1.521981 & 0.289194 & -5.262848 & 0.0000 \\
\hline LIMIT_3:C(13) & -0.221075 & 0.284558 & -0.776907 & 0.4372 \\
\hline LIMIT_4:C(14) & 0.738595 & 0.286500 & 2.577996 & 0.0099 \\
\hline LIMIT_5:C(15) & 1.486671 & 0.292679 & 5.079525 & 0.0000 \\
\hline LIMIT_6:C(16) & 1.916914 & 0.304605 & 6.293109 & 0.0000 \\
\hline LIMIT_7:C(17) & 2.283128 & 0.328822 & 6.943352 & 0.0000 \\
\hline LIMIT_9:C(18) & 2.401618 & 0.342391 & 7.014259 & 0.0000 \\
\hline Pseudo R-squared & 0.058549 & Akaike info criterion & & 2.944648 \\
\hline Schwarz criterion & 3.166875 & Log likelihood & & -423.6972 \\
\hline Hannan-Quinn criter. & 3.033584 & Restr. log likelihood & & -450.0471 \\
\hline LR statistic & 52.69969 & Avg. log likelihood & & -1.412324 \\
\hline Prob (LR statistic) & 0.000000 & & & \\
\hline
\end{tabular}




\section{Table 6}

Sample (adjusted): 2300

Included observations: 202 after adjustments

Number of ordered indicator values: 8

Convergence achieved after 4 iterations

\begin{tabular}{ccccc}
\hline \hline & Coefficient & Std. Error & Z-Statistic & Prob. \\
\hline \hline STATUS_2 & 0.463549 & 0.204076 & 2.271454 & 0.0231 \\
CHILDREN_3 & 0.128385 & 0.168174 & 0.763402 & 0.4452 \\
CHILDREN_4_5_6 & 0.257828 & 0.235916 & 1.092883 & 0.2744 \\
CH_CARE_2 & -0.065076 & 0.311325 & -0.209028 & 0.8344 \\
CH_CARE_3 & -0.137547 & 0.186816 & -0.736268 & 0.4616 \\
\hline \hline & \multicolumn{5}{c}{ Limit Points } & & \\
\hline \hline LIMIT_2:C(6) & -0.763718 & 0.190913 & -4.000344 & 0.0001 \\
LIMIT_3:C(7) & 0.417802 & 0.185373 & 2.253840 & 0.0242 \\
LIMIT_4:C(8) & 1.213909 & 0.195244 & 6.217397 & 0.0000 \\
LIMIT_5:C(9) & 1.920934 & 0.221731 & 8.663353 & 0.0000 \\
LIMIT_6:C(10) & 2.228114 & 0.244531 & 9.111774 & 0.0000 \\
LIMIT_7:C(11) & 2.477420 & 0.272864 & 9.079324 & 0.0000 \\
LIMIT_9:C(12) & 2.595962 & 0.290776 & 8.927709 & 0.0000 \\
\hline \hline
\end{tabular}




\section{Table 7}

Sample: 1146

Included observations: 146 - male

Number of ordered indicator values: 8

Convergence achieved after 5 iterations

\begin{tabular}{|c|c|c|c|c|}
\hline & Coefficient & Std. Error & z-Statistic & Prob. \\
\hline AGE_2 & -0.040494 & 0.273289 & -0.148172 & 0.8822 \\
\hline AGE_3 & -0.130870 & 0.350611 & -0.373262 & 0.7090 \\
\hline AGE_4 & -0.714121 & 0.352733 & -2.024537 & 0.0429 \\
\hline EDU_3_4 & 0.608964 & 0.252131 & 2.415269 & 0.0157 \\
\hline EDU_5 & 1.854249 & 0.373598 & 4.963227 & 0.0000 \\
\hline STATUS_2 & -0.034835 & 0.248388 & -0.140243 & 0.8885 \\
\hline ISCO_4_5_6 & 0.931966 & 0.383374 & 2.430958 & 0.0151 \\
\hline ISCO_7_8_9 & 0.369204 & 0.312338 & 1.182068 & 0.2372 \\
\hline OWNER_2 & 0.589960 & 0.284267 & 2.075374 & 0.0380 \\
\hline FIRM_SIZE_2 & 0.538385 & 0.356204 & 1.511453 & 0.1307 \\
\hline FIRM_SIZE_3 & 0.182242 & 0.323809 & 0.562807 & 0.5736 \\
\hline FIRM_SIZE_4 & 0.886421 & 0.363459 & 2.438849 & 0.0147 \\
\hline FIRM_SIZE_5 & 1.022033 & 0.367040 & 2.784526 & 0.0054 \\
\hline FIRM_SIZE_6 & 0.555240 & 0.361222 & 1.537114 & 0.1243 \\
\hline CHILDREN_2 & 0.460653 & 0.346107 & 1.330956 & 0.1832 \\
\hline CHILDREN_3 & 0.548022 & 0.347806 & 1.575655 & 0.1151 \\
\hline CHILDREN_4_5_6 & 1.519670 & 0.452838 & 3.355883 & 0.0008 \\
\hline \multicolumn{5}{|c|}{ Limit Points } \\
\hline LIMIT_2:C(18) & 0.127222 & 0.580897 & 0.219010 & 0.8266 \\
\hline LIMIT_3:C(19) & 1.643437 & 0.582259 & 2.822519 & 0.0048 \\
\hline LIMIT_4:C(20) & 2.792842 & 0.598179 & 4.668909 & 0.0000 \\
\hline LIMIT_5:C(21) & 3.736509 & 0.621885 & 6.008357 & 0.0000 \\
\hline LIMIT_6:C(22) & 4.217387 & 0.642792 & 6.561041 & 0.0000 \\
\hline LIMIT_7:C(23) & 4.952239 & 0.721809 & 6.860876 & 0.0000 \\
\hline LIMIT_9:C(24) & 5.329673 & 0.790798 & 6.739617 & 0.0000 \\
\hline Pseudo R-squared & 0.128990 & Akaike info criterion & & 3.013529 \\
\hline Schwarz criterion & 3.503984 & Log likelihood & & -195.9876 \\
\hline Hannan-Quinn criter. & 3.212812 & Restr. log likelihood & & -225.0118 \\
\hline LR statistic & 58.04852 & Avg. log likelihood & & -1.342381 \\
\hline Prob (LR statistic) & 0.000002 & & & \\
\hline
\end{tabular}




\section{Table 8}

Sample: 1154

Included observations: 154 - female

Number of ordered indicator values: 6

Convergence achieved after 5 iterations

\begin{tabular}{|c|c|c|c|c|}
\hline & Coefficient & Std. Error & z-Statistic & Prob. \\
\hline AGE_2 & 0.930515 & 0.342273 & 2.718633 & 0.0066 \\
\hline AGE_3 & 0.416318 & 0.354528 & 1.174288 & 0.2403 \\
\hline AGE_4 & 0.318844 & 0.351262 & 0.907710 & 0.3640 \\
\hline EDU_3_4 & 0.114108 & 0.193134 & 0.590822 & 0.5546 \\
\hline STATUS_2 & -0.015613 & 0.205039 & -0.076149 & 0.9393 \\
\hline ISCO_4_5_6 & -1.010093 & 0.226047 & -4.468511 & 0.0000 \\
\hline ISCO_7_8_9 & -2.266329 & 0.346404 & -6.542446 & 0.0000 \\
\hline OWNER_2 & 0.441097 & 0.219085 & 2.013362 & 0.0441 \\
\hline FIRM_SIZE_2 & 0.718095 & 0.352526 & 2.036998 & 0.0417 \\
\hline FIRM_SIZE_3 & 0.236085 & 0.320149 & 0.737421 & 0.4609 \\
\hline FIRM_SIZE_4 & 1.325448 & 0.355698 & 3.726329 & 0.0002 \\
\hline FIRM_SIZE_5 & 1.086004 & 0.395652 & 2.744848 & 0.0061 \\
\hline FIRM_SIZE_6 & 0.416711 & 0.408374 & 1.020415 & 0.3075 \\
\hline CHILDREN_2 & -0.456011 & 0.314831 & -1.448432 & 0.1475 \\
\hline CHILDREN_3 & -0.214396 & 0.301759 & -0.710487 & 0.4774 \\
\hline CHILDREN_4_5_6 & -0.252446 & 0.409450 & -0.616550 & 0.5375 \\
\hline \multicolumn{5}{|c|}{ Limit Points } \\
\hline LIMIT_2:C(17) & -1.088943 & 0.402408 & -2.706069 & 0.0068 \\
\hline LIMIT_3:C(18) & 0.547916 & 0.397043 & 1.379991 & 0.1676 \\
\hline LIMIT_4:C(19) & 1.779681 & 0.421870 & 4.218552 & 0.0000 \\
\hline LIMIT_5:C(20) & 2.620059 & 0.471338 & 5.558769 & 0.0000 \\
\hline LIMIT_9:C(21) & 3.231512 & 0.548540 & 5.891118 & 0.0000 \\
\hline Pseudo R-squared & 0.168019 & Akaike info criterion & & 2.493625 \\
\hline Schwarz criterion & 2.907755 & Log likelihood & & -171.0091 \\
\hline Hannan-Quinn criter. & 2.661844 & Restr. log likelihood & & -205.5444 \\
\hline LR statistic & 69.07059 & Avg. log likelihood & & -1.110449 \\
\hline Prob (LR statistic) & 0.000000 & & & \\
\hline
\end{tabular}




\section{WAGE DETERMINATION WITH SPECIAL REFERENCE TO ROLE IN A FAMILY}

\section{Lenka Filipová, Zuzana Machová}

VŠB - Technical University of Ostrava, Faculty of Economics, Sokolská třída 33, 701 21 Ostrava 1, lenka.filipova@vsb.cz, zuzana.machova@vsb.cz

Abstract: The paper has arisen as a part of the project dealing with the questions of measuring of wage determinants and wage discrimination on the basis of different subjective requirements of women and men on their wages. Using the ordered-response model (Ordered Probit), it analysed wage determination on the basis of Mincer's Wage Regression including dummies for role in a family. The analysis was carried out with the total sample of respondents and subsequently separately for men and women. The data were gained from a questionnaire survey carried out in Ostrava city, Czech Republic. In general, the analysis did not prove previous conclusions of theories or empirical studies about prevailing influence of family characteristics on the wage rate. Nevertheless, it proved statistically significant differences in the wage determination between men and women, and showed that in the case of men, some family characteristics may have been important for determining the wages.

Key words: Human Capital, Role in a Family, Wage Determinants, Wage Discrimination.

JEL Classification: J24, J31, J71

DOI: $10.2478 / \mathrm{v} 10135-011-0006-\mathrm{y}$ 